\title{
VARIATION IN PLANT DEFENSES OF DIDYMOPANAX VINOSUM (CHAM. \& SCHLTDL.) SEEM. (APIACEAE) ACROSS A VEGETATION GRADIENT IN A BRAZILIAN CERRADO
}

\author{
Mara Patrícia Pais ${ }^{1}$ \\ Elenice Mouro Varanda ${ }^{1}$
}

Received: 25/03/2002. Accepted: 17/01/2003

\begin{abstract}
Variation in plant defenses of Didymopanax vinosum (Cham. \& Schltdl.) Seem. (Apiaceae) across a vegetation gradient in a Brazilian cerrado). Cerrado vegetation is composed of a mosaic of vegetation types, from campo sujo, dominated by herbs; campo cerrado and cerrado sensu stricto, with shrubby vegetation; to cerradão, with trees forming a denser forest. This physiognomic mosaic is related to differences in the water availability in the soil. Cerrado plants are considered physically and chemically well defended against herbivores, but there are no studies showing how plants allocate investment to various types of defensive mechanisms in different habitat physiognomies. The defensive mechanisms and the nutritional traits of a cerrado plant, Didymopanax vinosum (Cham. \& Schltdl.) Seem. (Apiaceae), were compared along a vegetation gradient. Toughness, as well as water, nitrogen, cellulose, lignin, and tannin contents were measured in young and mature leaves of $D$. vinosum collected in campo cerrado, cerrado sensu stricto (s.s.) and cerradão. Plants from cerrado s.s. and cerradão were of better nutritional quality but also had higher tannin contents than campo cerrado plants. Some type of compensation mechanism could have been selected to provide an optimum investment in defense, according to limitations imposed by water deficits in the habitat.
\end{abstract}

Key words - cerrado, plant defenses, tannins, vegetation gradient, water stress

RESUMO - (Variações no investimento em defesas em Didymopanax vinosum (Cham. \& Schltdl.) Seem. (Apiaceae) ao longo de um gradiente de vegetação num cerrado brasileiro). A vegetação de cerrado é composta por um mosaico de fisionomias, abrangendo desde o campo sujo, dominado por herbáceas, passando pelo campo cerrado e cerrado sensu stricto, com predomínio de vegetação arbustiva, até o cerradão, basicamente uma formação florestal. Este mosaico fisionômico está relacionado com diferenças na disponibilidade de água no solo. Considera-se que as plantas de cerrado são física e quimicamente bem protegidas contra herbívoros, embora não existam estudos mostrando como as plantas investem em defesas nas diferentes fisionomias. Nosso objetivo foi comparar o investimento em algumas defesas e caracteres nutritivos em Didymopanax vinosum (Cham. \& Schltdl.) Seem. (Apiaceae), uma espécie vegetal típica de cerrado, ao longo de um gradiente fisionômico. Foram mensurados a dureza e os conteúdos de água, nitrogênio, celulose, lignina e taninos de folhas jovens e adultas de $D$. vinosum coletadas no campo cerrado, cerrado sensu stricto (s.s.) e cerradão. As plantas de cerrado s.s. e do cerradão apresentaram melhores características nutritivas, mas também maiores valores de taninos que as plantas do campo

2 Departamento de Biologia, FFCLRP/USP, Av. Bandeirantes 3900, CEP 14040-901, Ribeirão Preto, SP, Brazil (paism@ usp.br; emvarand@ffclrp.usp.br) 
cerrado. Discute-se a possibilidade de que algum mecanismo de compensação tenha sido selecionado de modo a proporcionar um investimento ótimo em defesas, respeitando as limitações impostas pelo déficit de água no ambiente.

Palavras chave - cerrado, defesas vegetais, estresse hídrico, gradiente de vegetação, taninos

\section{Introduction}

Cerrado is a typical biome found in Central Brazil that occupies nearly $25 \%$ of Brazilian territory (Joly 1970). However, it has been destroyed at rates higher than has the Amazonian forest (Price et al. 1995). In view of this, studies of cerrado habitats are of great importance.

What we call cerrado sensu lato is not a homogeneous type of vegetation. It is composed of a gradient of vegetation types, from communities dominated by herbs (campo sujo) or shrubs (campo cerrado, cerrado sensu stricto), to those with trees forming a closed canopy (cerradão) (Goodland 1971b).

Typical cerrado is usually found in regions receiving from about 1,000 to $1,500 \mathrm{~mm}$ of rainfall per year (sometimes as much as $1,700 \mathrm{~mm}$ ), although they have from five to six dry months (Alvim 1999). The first studies about cerrado concluded that the typical scleromorphic traits of the plant species (thick bark, tough leaves covered with a thick layer of trichomes, and stomata in depressions) were adaptations to the water stress during drought periods (Warming \& Ferri 1973). However, in the late 1940s through the 50s, scientists began to attribute cerrado scleromorphism to oligotrophic soil conditions, as stated by the "oligotrophic scleromorphism theory" (Arens 1958). These oligotrophic conditions principally involve phosphate, nitrogen and potassium deficits (Goodland \& Ferri 1979). Consequently, campo sujo vegetation would develop in more oligotrophic soils, while cerradão would occupy the other extreme, that is, more fertile soils. Later, the term "aluminotoxic scleromorphism" was proposed because the vegetation gradient also accompanies the levels of aluminum in cerrado soils (Goodland 1971a). The mosaic pattern of the effect of fire, very common in cerrado areas, could also result in a complex of altered communities by altering soil fertility (Goodland \& Pollard 1973) and by changing the vegetation structure (Coutinho 1982). Nowadays, it is known that the presence of a particular cerrado physiognomy is dependent on the interaction of several factors, such as soil depth, fertility, drainage capacity, occurrence of a superficial hardpan, fire, wood cutting and cattle grazing (Pivello \& Coutinho 1996). Among these factors, water availability, in general related to the holding capacity of soils, has gained importance as one of the mains edaphic factors in cerrado (Alvim \& Silva 1980; Alvim 1996; 1999). Seasonal fluctuations in the water table level have also been considered decisive for the water availability to the plant community (Oliveira-Filho et al. 1989). A recent study at ARIE (Area de Relevante Interesse Ecológico) Cerrado Pé-de-Gigante, state of São Paulo, multivariate analysis of soil chemical and physical traits showed no distinction among cerrado physiognomies (Ruggiero 2000). This researcher believes that the different physiognomies are determined by a more complex combination of factors, principally related to water dynamics in the subsurface and in the subsoil.

The vegetation gradient in the Pé-de-Gigante Cerrado provides an appropriate system to study the relationship between a plant gradient based on water limitations and plant investment in antiherbivore defenses. Fowler and Duarte (1991), studying various cerrado plant species, suggested that the pressure by herbivorous insects is low (4.6-9.3\%) in this type of vegetation due to the selection of plant defense strategies. Nascimento 
et al. (1990) noticed this low level of herbivory in Vockysia rufa and Curatella americana. Marquis et al. (2001) estimated the mean herbivory by insects in 25 plant species of cerrado as $6.8 \%$, with interspecific variation from $1 \%$ to $15 \%$. They found a negative correlation between protein-binding capacity in leaves (generally related to tannin contents) and insect damage. The only exception to this low herbivory pattern seems to be the gall-forming insects guild, which generally benefit from the protection provided by tannin accumulation around the gall tissues (Ribeiro \& Fernandes 2000).

According to Salatino (1993), the scleromorphism syndrome has been selected by cerrado plants as a defense against herbivores, principally insects, rather than as result of edaphic or moisture conditions. Although the richness of insects has been studied in cerrado gradients in recent years (Fernandes \& Price 1988; 1991; Ribeiro et al. 1994; Carneiro et al. 1995; Fernandes et al. 1997; Ribeiro et al. 1998; Gonçalves-Alvim \& Fernandes 2001), studies about how cerrado plants allocate investment in different types of anti-herbivory defenses in the several physiognomies are yet at an incipient stage (Madeira et al. 1998).

In this study, some of the defenses and the nutritional traits of leaves of a common plant species in cerrado, Didymopanax vinosum (Apiaceae), were measured along a vegetation gradient, to test two hypotheses:

1) The resource availability hypothesis, which postulates that plant species growing in resource-limited environments tend to be inherently less flexible than other species in their responses to changes in availability of resources (Coley et al. 1985). If so, the leaf traits should not change among the physiognomies;

2) The growth-differentiation balance (GDB) hypothesis, generally used to explain phenotypic variation, according to which sink limitations imposed by extrinsic factors such as moderate drought would result in the accumulation of carbohydrates, and increased concentrations of secondary metabolites (Lorio 1986). Based on this hypothesis, we would expect an increasing defense gradient from cerradão to campo cerrado, the driest area.

\section{Material and methods}

This study was performed at Pé-de-Gigante Cerrado $\left(21^{\circ} 36^{\prime} 44^{\prime \prime} \mathrm{S}\right.$ and $\left.47^{\circ} 34^{\prime} 41^{\prime \prime} \mathrm{W}\right)$, that is situated at the Parque Estadual de Vassununga, in Santa Rita do Passa Quatro, SP, Brazil. This area, which is predominantly composed of typical cerrado sensu lato vegetation, covers an area of 900 ha (Martins 1991). There are two well-defined seasons: a wet season from November to April, with approximately $1,200 \mathrm{~mm}$ of rainfall, and a dry season, from May to October, with $485 \mathrm{~mm}$ of rainfall. The monthly average temperature ranges from $17^{\circ} \mathrm{C}$ in June, to $25^{\circ} \mathrm{C}$ in January. The vegetation is characterized by physiognomies of campo cerrado, cerrado sensu stricto (s.s.) and cerradão, as well as riparian forest and semideciduous forest. The campo cerrado vegetation is open and dominated by herbs, shrubs up to $2 \mathrm{~m}$ in height, and scattered trees from 7 to $10 \mathrm{~m}$ in height. The cerrado s.s. formation is composed of shrubs and trees approximately $5 \mathrm{~m}$ in height and of emerging trees 7 to $10 \mathrm{~m}$ in height. Cerradão is regarded as a forest formation because it has a welldeveloped arboreal layer. In cerradão, trees approximately $10 \mathrm{~m}$ in height predominate and the herbaceous and shrubby components are poorly developed (Batalha 1997).

Didymopanix vinosum is a compound-leaf shrub, typical of cerrado in São Paulo State. This species was chosen because of its high abundance in all of the three physiognomies described above. In cerrado s.s. and cerradão, this species is mainly found in small clearings (unpublished data).

In April, July and October/1997, and in January/1998, nine $D$. vinosum shrubs greater than $1 \mathrm{~m}$ in height were selected in an area of 
approximately $10,000 \mathrm{~m}^{2}$ in each physiognomy. About 50 leaves/plant were collected and samples of three individuals were grouped in order to obtain three field replicates/ physiognomy. Water, nitrogen, cellulose, lignin and tannin content as well as leaf toughness were evaluated. All assays were run separately on young, expanding leaves and on mature, totally expanded leaves.

To evaluate water content, the leaves were separated from their petioles and weighed while they were still in the field and then dried at $40^{\circ} \mathrm{C}$, until they reached a constant weight. The water content was expressed as a percentage of the fresh weight. The leaves were then powdered for chemical analyses. Total nitrogen quantification was carried out using the micro-Kjeldahl method (Allen et al. 1974). Cellulose and lignin were quantified by the Van Soest and Robertson method (1979). For measurements of leaf toughness, 30-35 fresh leaflets were selected from different leaves. Measurements were carried out using a penetrometer that determines the pressure necessary (in $\mathrm{mmHg} \mathrm{cm}-2$ ) to perforate a circle $2 \mathrm{~mm}$ in diameter through the leaf lamina. This device was constructed according to the instructions of King (1988). Three measurements were made in the median region of each leaflet to avoid touching the main vein. Tannins were quantified according to the protein precipitation method (Hagerman \& Butler 1978).

Comparisons between young and mature leaves were carried out using the $t$-test or Mann-Whitney rank sum test, according to data normality. For comparisons of the same variable in different areas, a Kruskal-Wallis one way ANOVA on ranks was applied, followed by the Dunn's method for multiple comparisons among data groups (Sokal \& Rohlf 1981). As no seasonal pattern was found for these factors, data from the four sample periods were combined, giving $\mathrm{n}=12$.

\section{Results and discussion}

Young leaves had a higher water (MannWhitney rank sum test; $P<0.0001 ; N=12)$ and nitrogen content ( $t$-test; $P<0.05 ; N=12$ ), a lower cellulose and lignin content (MannWhitney rank sum test; $P<0.0001 ; N=12$ ), lower tannin concentrations $(t$-test; $P<0,05$; $N=12)$ and were less tough ( $t$-test; $P<0.0001$, $N=12$ ) than mature leaves.

Several of the leaf traits varied from one physiognomy to another. In general, leaves from campo cerrado had lower water and nitrogen contents (Fig. 1a, 1b, 2a and 2b), higher cellulose and lignin contents (Fig. 1c, 1d, 2c and 2d), were tougher (Fig. 1e and 2e) and had lower tannin content (Fig. 1f and 2f) than leaves from cerrado s.s. and cerradão.

According to the "resource availability hypothesis", plant species growing in resourcelimited environments tend to be less flexible than other species in their responses to changes in the availability of resources (Coley et al. 1985). However, there was great variation among physiognomies in the magnitude of all traits analyzed in D. vinosum, a typical species in a resource-limited environment (cerrado) (Fig. 1 and 2). Studies with species from other resourcelimited habitats also reported spatial variation in plant defenses (e. g. Louda 1987; Pisani \& Distel 1998). Cates and Redak (1988) reviewed several studies showing that variation in plant defensive chemistry, nutrition, and morphology is correlated with reduced herbivore success within and among plant populations.

Although plants of cerrado s.s. and cerradão were quite similar in their leaf traits, those from campo cerrado were better defended against herbivores, based on five out of six measures (Fig. 1 and 2). Interestingly, the inverse was observed in relation to tannin contents, which were higher in cerrado s.s. and cerradão (Fig. 2f). It seems that there is compensation by these plants for the more nutritive attributes. Considering again the possibility of a 

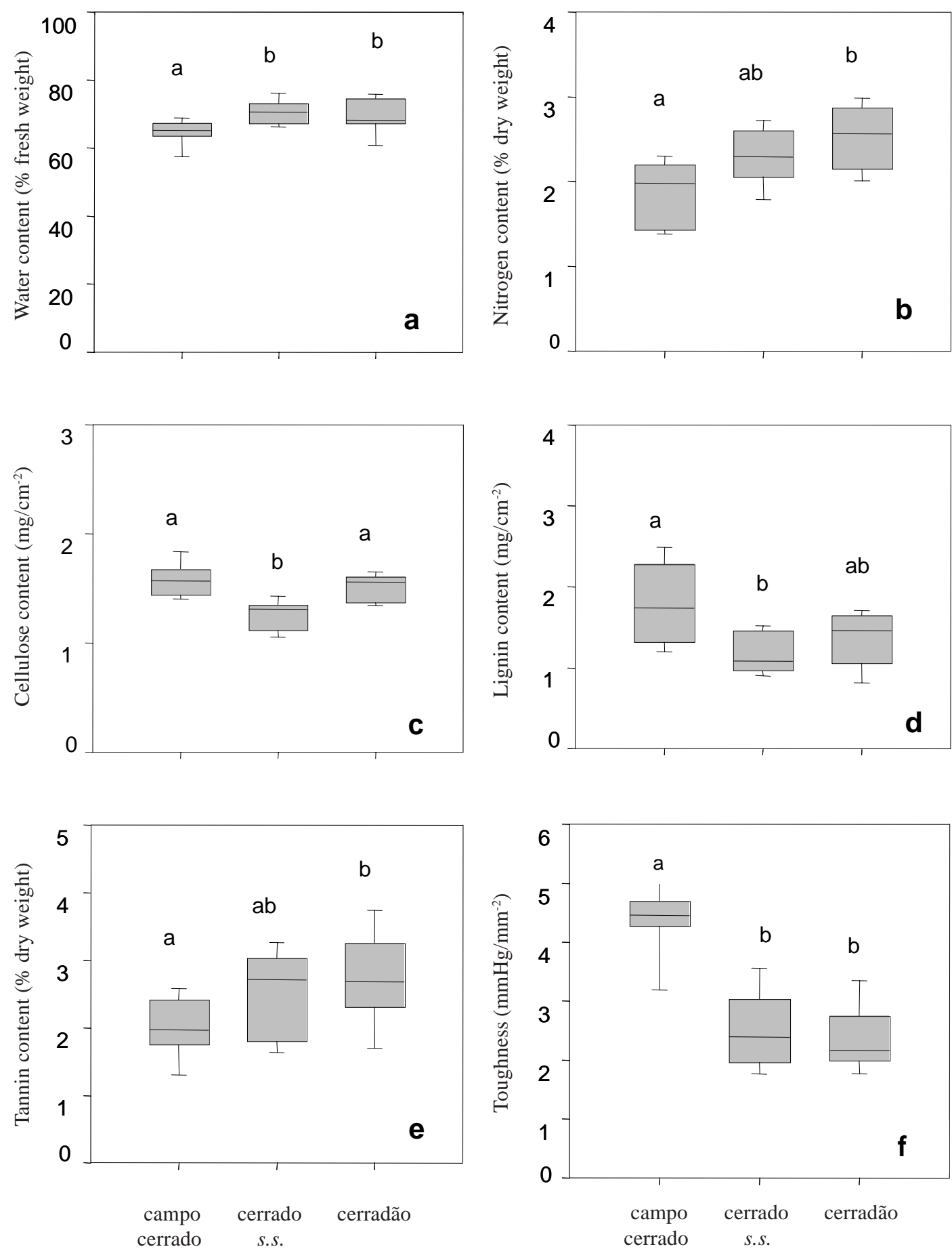

Figure 1. Water (a), nitrogen (b), cellulose (c), lignin (d) and tannin (e) contents, and toughness (f) of young leaves of Didymopanax vinosum collected in three cerrado physiognomies. Different letters indicate significant differences among leaves $(P<0.0001$ for toughness and $P<0.05$ for the other parameters; $N=12$; Kruskal-Wallis One Way ANOVA on Ranks - Dunn's Method). 

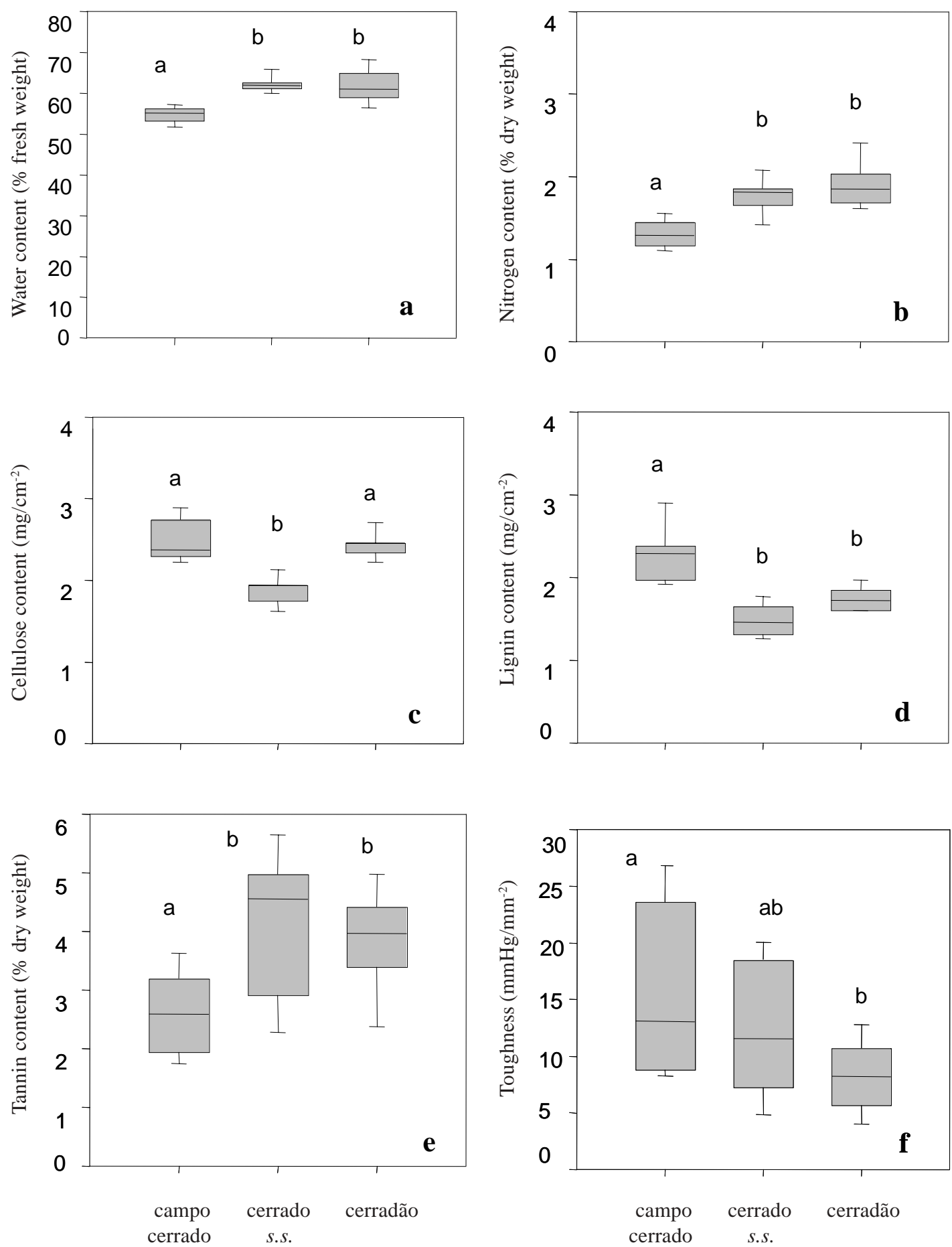

Figure 2. Water (a), nitrogen (b), cellulose (c), lignin (d) and tannin (e) contents, and toughness (f) of mature leaves of Didymopanax vinosum collected in three cerrado physiognomies. Different letters indicate significant differences among leaves $(P<0.0001$ for toughness and $P<0.05$ for the other parameters; $N=12$; Kruskal-Wallis One Way ANOVA on Ranks - Dunn's Method). 
gradient of water stress, our results also partially corroborate the predictions of the "growth-differentiation balance hypothesis" (GDB). The GDB hypothesis predicts that sink limitation imposed by extrinsic factors such as moderate drought will result in the accumulation of carbohydrates, and increased concentrations of secondary metabolites (Lorio 1986). In fact, the leaves from campo cerrado, the most water-limited area, had the highest lignin contents and consequently the highest toughness values, both of which are characters derived from secondary metabolism. On the other hand, leaves from this area had the lowest contents of tannins, one of the more widespread secondary metabolite classes. This latter finding is opposite to what would be expected, since several theories predict that plants exposed to lower resource availability would have higher investment in quantitative defenses, including tannins. (Coley et al. 1985; Lorio 1986; Herms \& Mattson 1992). However, these predictions have not always been confirmed. Gershenzon (1984) gave many examples where plants in fact exhibit a variety of phenol-based responses to water deficits. In another study, Madeira et al. (1998) did not observe variation in tannin concentrations in Chamaecrista linearifolia (Fabaceae) along an altitudinal gradient in a cerrado area. However, these authors found that leaves tended to be smaller and more sclerophyllous at increasing altitudes, where soils are generally more exposed and shallower, and have reduced nutrient availability and lower moisture-retaining capacity.

Water deficits during the dry months in cerrado areas result in severe restriction for gas exchange as well as partial leaf fall and a decrease in osmotic potential in the remaining leaves in several plant species (Moraes \& Prado 1998). Further studies are required to elucidate how these physiological changes affect the metabolism of nutrients and secondary compounds. Whatever the physiological mechanisms responsible for these different trends in defense investment in the various physiognomies, $D$. vinosum seems to have been selected to converge to an optimum in defense, so that low investments in some types of defense are compensated by higher investments in others.

\section{Acknowledgments}

This project was supported by CAPES, FAPESP (Proc. 96/8148-0) and CNPq. We thank Waldir Mantovani for helping to determine the physiognomies, as well as Kleber Del-Claro, Silvana Aparecida Pires de Godoy for their important comments and suggestions.

\section{References}

Allen, S. E.; Grimshaw, H. M.; Parkinson, J. A. \& Quarmby, C. 1974. Chemical analysis of ecological materials. Blackwell Scientific Publications, Oxford.

Alvim, P. de T. 1996. Repensando a teoria da formação dos campos cerrados. Pp. 56-58. In Anais do VIII simpósio sobre o cerrado: biodiversidade e produção de alimentos e fibras nos cerrados. Embrapa, Brasília.

Alvim, P. de T. 1999. Soil of the humid tropics and their sustainable use. Pp. 89-109. In Workshop on Tropical Soils. Academia Brasileira de Ciências, Rio de Janeiro.

Alvim, P. de T. \& Silva, J. E. 1980. Comparação entre os cerrados e a região amazônica em termos agroecológicos. Pp. 143-160. In Cerrado: uso e manejo. EMBRAPA/CPAC, CNPQ, Ed. Editerra, Brasília.

Arens, K. 1958. O cerrado como vegetação oligotrófica. Boletim da Faculdade Filosofia, Ciências e Letras, Universidade São Paulo, Botânica 15: 69-77.

Batalha, M. A. 1997. Análise da vegetação da ARIE Cerrado Pé-de-Gigante (Santa Rita do Passa Quatro, SP). Master Thesis. Instituto de Biociências, USP, São Paulo.

Carneiro, M. A. A.; Ribeiro, S. P. \& Fernandes, G. W. 1995. Artrópodes de um gradiente altitudinal na Serra do Cipó, Minas Gerais, Brasil. Revista Brasileira de Entomologia 39(3): 597-604. 
Cates, R. C. \& Redak R. A. 1888. Variation in the terpene chemistry of Douglas-fir and its relationship to western spruce budworm success. Pp. 317-344 In K. Spencer (ed.). Chemical mediation of coevolution. Academic Press, New York.

Coley, P. D.; Bryant, J. P. \& Chapin, F. S. III. 1985. Resource availability and plant antiherbivory defense. Science 230: 895-899.

Coutinho, L. M. 1982. Ecological effects of fire in Brazilian cerrado. Ecological Studies 42, Ecology of tropical savannas: 273-291.

Fernandes, G. W.; Araújo, L. M.; Carneiro, M. A. A.; Cornelissen, T. G.; Barcelos-Greco, M. C.; Lara, A. C. F. \& Ribeiro, S. P. 1997. Padrões de riqueza de insetos em gradientes altitudinais na Serra do Cipó, Minas Gerais. Pp. 191-195. In L. L. Leite \& C. H. Saito (org.). Contribuição ao conhecimento ecológico do cerrado - trabalhos selecionados do $3^{\circ}$ Congresso de Ecologia do Brasil. Departamento Ecologia, Universidade de Brasília, Brasília.

Fernandes, G. W. \& Price, P. W. 1988. Biogeographical gradients in galling species richness - tests of hypotheses. Oecologia 76: 161-167.

Fernandes, G. W. \& Price, P. W. 1991. Comparison of tropical and temperate galling species richness: the role of environmental harshness and plant nutrient status. Pp. 91-115. In P. W. Price; G. W. Lewinsohn; G. W. Fernandes \& W. W. Benson (eds.). Plant-animal interactions: evolutionary ecology in tropical and temperate regions. Wiley, New York.

Fowler, H. G. \& Duarte, L. C. 1991. Herbivore pressure in a Brazilian Cerrado. Naturalia 16: 99-102.

Gershenzon, J. 1984. Changes in the levels of plant secondary metabolite production under water and nutrient stress. Pp. 273-320. In B. N. Timmermann; C. Steelink; F. A. Loewus (eds.). Phytochemical adaptations to stress. Recent Advances in Phytochemistry, Vol. 18, Plenum Press, New York.

Gonçalves-Alvim S. J. \& Fernandes, G. W. 2001. Biodiversity of galling insects: historical, community and habitat effects in four neotropical savannas. Biodiversity and Conservation 10(1): 79-98.

Goodland, R. J. A. 1971a. Oligotrofismo e alumínio no cerrado. Pp. 44-60. In M. G. Ferri (coord.). III Simpósio sobre o Cerrado. EDUSP and Edgard Blücher, São Paulo.
Goodland, R. J. A. 1971b. A physiognomic analysis of the "cerrado" vegetation of central Brazil. Journal of Ecology 59: 411-419.

Goodland, R. J. A. \& Ferri, M. G. 1979. Ecologia do cerrado. Ed. da Universidade de São Paulo, São Paulo.

Goodland, R. J. A. \& Pollard, R. 1973. The Brazilian cerrado vegetation. A fertility gradient. Journal of Ecology 61: 219-224.

Hagerman, A. E. \& Butler, L. G. 1978. Protein precipitation method for the quantitative determination of tannins. Journal of Agriculture \& Food Chemistry 26(4): 809-812.

Herms, D. A. \& Mattson, W. J. 1992. The dilemma of plants: to grow or defend. Quarterly Review in Biology 67: 283-335.

Joly, A. B. 1970. Conheça a vegetação brasileira. EDUSP \& Editora Polígono, São Paulo.

King, B. L. 1988. Design and evaluation of a simple penetrometer for measuring leaf toughness in studies of insect herbivory. Virginia Journal of Science 39(4): 405-408.

Lorio, P. L. Jr. 1986. Growth-differentiation balance: a basis for understanding southern pine beetle-tree interactions. Forest Ecological Management 14: 259-273.

Louda, S. M. 1987. Variation in methylglucosinolate and insect damage to Cleome serrulata (Capparaceae) along a natural soil moisture gradient. Journal of Chemical Ecology 13(3): 596-581.

Madeira, J. A.; Ribeiro, K. T. \& Fernandes, G. W. 1998. Herbivory, tannins and sclerophylly in Chamaecrista linearifolia (Fabaceae) along an altitudinal gradient. Brazilian Journal of Ecology 2: 24-29.

Marquis, R. J.; Diniz, I. R. \& Morais, H. C. 2001. Patterns and correlates of interspecfic variation in foliar insect herbivory and pathogen attack in Brazilian cerrado. Journal of Tropical Ecology 17: 127-148.

Martins, F. R. 1991. Estrutura de uma floresta mesófila. Série Teses, Editora da UNICAMP, Campinas.

Moraes, J. A. P. V. \& Prado C. H. B. A. 1998. Photosynthesis and water relationships in cerrado vegetation. Pp. 45-63. In F. R. Scarano \& A. C. Franco (eds). Ecophysiological strategies of xerophytic and amphibious plants in the neotropics. Série Oecologia Brasiliensis, vol. IV. PPGE-UFRJ. Rio de Janeiro, Brazil. 
Nascimento, M. T.; Villela, D. M. \& Lacerda, L. D. 1990. Foliar growth, longevity and herbivory in two "cerrado" species near Cuiabá, MT, Brazil. Revista Brasileira de Botânica 13: 27-32.

Oliveira-Filho, A. T.; Shepherd, G.J.; Martins, F. R. \& Stubblebine, W. H. 1989. Environmental factors affecting physiognomic and floristic variation in an area of cerrado in central Brazil. Journal of Tropical Ecology 5: 413-431.

Pisani, J. M. \& Distel, R. A. 1998. Inter- and intraspecific variations in production of spines and phenols in Prosopis caldenia and Prosopis flexuosa. Journal of Chemical Ecology 24(1): 23-36.

Pivello, V. R. \& Coutinho, L. M. 1996. A qualitative successional model to assist in the management of Brazilian cerrados. Forest Ecology and Management 87: 127-138.

Price, P. W.; Diniz, I. R.; Morais, H. C. \& Marques, E. S. A. 1995. The abundance of insect herbivore species in the tropics: the high local richness of rare species. Biotropica 27(4): 468-478.

Ribeiro, S. P.; Carneiro, M. A. A. \& Fernandes, G. W. 1994. Distribution of Brachypnoea (Coleoptera: Chrysomelidae) in an altitudinal gradient in a Brazilian savanna vegetation. Phytophaga 6: 29-33.

Ribeiro, S. P.; Carneiro, M. A. A. \& Fernandes, G. W. 1998. Free-feeding insect herbivores along environmental gradients in Serra do Cipó: basis for a management plan. Journal of Insect Conservation 2: 107-118.
Ribeiro, S. P. \& Fernandes, G. W. 2000. Interações entre insetos e plantas no cerrado: teoria e hipóteses de trabalho. Pp. 299-320. In R. P. Martins; T. M. Lewinsohn \& M. S. Barbeitos (eds). Ecologia e comportamento de insetos. Série Oecologia Brasiliensis, vol. VIII. PPGE-UFRJ. Rio de Janeiro, Brasil.

Ruggiero, P. G. C. 2000. Levantamento pedológico relacionado às fisionomias encontradas na Gleba Cerrado Pé-de-Gigante, Parque Estadual de Vassununga, Santa Rita do Passa Quatro, SP. Master Thesis. Instituto de Biociências, USP, São Paulo.

Salatino, A. 1993. Chemical ecology and the theory of oligotrophic scleromorphism. Anais da Academia Brasileira Ciências 65(1): 1-13.

Sokal, R. R. \& Rohlf, F. J. 1981. Biometry. $2^{\text {nd }}$ ed., W. H. Freeman and Company, New York.

Van Soest, P. J. \& Robertson J. 1979. Systems of analysis for evaluating fibrous feeds. Pp. 49-60. In W. I. Pigden; C. C. Balch \& M. Graham (eds.). Standardization of analytical methodology for feeds. International Development Research Center Ottawa, Canadá.

Warming, E. \& Ferri, M. G. 1973. Lagoa Santa / A vegetação de cerrados brasileiros. Belo Horizonte, Itatiaia \& Ed. da Universidade de São Paulo. 